\title{
Environmental temperature and choice feeding of the broiler
}

\author{
BY P. J. COWAN AND W. MICHIE \\ North of Scotland College of Agriculture, 58 1 King Street, Aberdeen AB9 IUD
}

(Received 29 June 1977 - Accepted 19 October 1977)

I. Broilers were kept under environmental temperature regimens of $I 6,21,26$ or $3 I^{\circ}$ and given, 22-57 d of age, either a complete diet or free-choice of whole wheat and a higher-protein food containing either 252 or $516 \mathrm{~g}$ crude protein (nitrogen $\times 6.25) / \mathrm{kg}$.

2. Broilers maintained at $\mathrm{I} 6$ and $2 \mathrm{I}^{\circ}$ consumed food at a significantly higher rate than those kept at $26^{\circ}$ and the latter had a significantly higher food intake rate than broilers kept at $31^{\circ}$, for each feeding treatment. Compared with $21^{\circ}$ the $57 \mathrm{~d}$ body-weight of broilers kept at $26^{\circ}$ and $31^{\circ}$ was significantly reduced.

3. When kept under the $16,21,26$ and $31^{\circ}$ regimens, the amount of whole wheat in the food consumed by the broilers choice-fed with wheat and the $252 \mathrm{~g}$ crude protein $/ \mathrm{kg}$ food was $56,55,48$ and $46 \%$ respectively. The corresponding values for the broilers on the second choice-feeding treatment were $80,76,79$ and $72 \%$.

4. Except for a single instance the choice-fed broilers grew at a significantly slower rate than broilers given the complete diet.

Cowan \& Michie (1978a) reported a study in which broilers were offered a free-choice of whole wheat and a higher-protein food containing either 250 or $515 \mathrm{~g}$ crude protein (nitrogen $\times 6.25) / \mathrm{kg}$. The broiler apparently balances its intake of these foods well. The dietary energy intake of animals changes with environmental temperature (e.g. Vohra, Wilson \& Siopes, 1975). When allowed to self-select from suitable protein and energy foods the domestic rat and mouse appear able to match their dietary energy and protein requirement under different environmental temperatures (Donhoffer \& Vonotsky, I947; Leshner, Collier \& Squibb, 1971; Musten, Peace \& Anderson, 1974). The present experiment was designed to evaluate the choice-feeding performance of the broiler kept under environmental temperature regimens of $\mathrm{I} 6,2 \mathrm{I}, 26$ or $3 \mathrm{I}^{\circ}$.

\section{EXPERIMENTAL}

The $I 6^{\circ}$ temperature regimen was started at $31^{\circ}$ when the broilers were housed at $1 \mathrm{~d}$ old. The temperature was lowered by $1^{\circ}$ on alternate days: $30^{\circ}$ at $3 \mathrm{~d}$ old, $29^{\circ}$ at $5 \mathrm{~d}$ old $\ldots 20^{\circ}$ at $23 \mathrm{~d}$ old, after which the temperature was dropped $1^{\circ}$ every day until at $27 \mathrm{~d}$ old the temperature was $16^{\circ}$. This temperature was maintained until the end of the experiment at $57 \mathrm{~d}$ old. The 21 and $26^{\circ}$ temperature regimens were established in the same way as the $16^{\circ}$ temperature regimen, until the appropriate temperature was reached and maintained. The $31^{\circ}$ temperature regimen was maintained at $3 \mathrm{r}^{\circ}$ from $\mathrm{I} \mathrm{d}$ old.

Composition of the foods used is given in Table $\mathrm{I}$. Diets nos 2 and 3 were formulated by omitting respectively $500 \mathrm{~g}$ wheat $/ \mathrm{kg}$ and all the wheat and maize from the specification of diet no. I. The three feeding treatments were the 'finisher' diet (diet no. I) with no choice, free-choice whole wheat and diet no. 2 and free-choice whole wheat and diet no. 3. Diets nos I, 2 and 3 were fed in pellet form $(3.175 \mathrm{~mm}$ pellet).

Ross I female broilers were used. The birds were initially housed in the top two tiers of a three-tier battery block in each of eight controlled-environment rooms and given 'starter' crumbs (50\% wheat, 25\% maize) containing, by calculation, $205 \mathrm{~g}$ crude protein and I I.99 MJ metabolizable energy (ME)/ $\mathrm{kg}$. Temperature regimens were randomly assigned to individual rooms, two rooms per regimen. 
Table I. Composition of the experimental foods

\begin{tabular}{|c|c|c|c|}
\hline Ingredients $(\mathrm{g} / \mathrm{kg})$ & $\begin{array}{l}\text { Complete } \\
\text { diet } \\
\text { (diet no. I) }\end{array}$ & Diet no. 2 & Diet no. 3 \\
\hline wheat & 715 & 430 & 一 \\
\hline maize & 100 & 200 & - \\
\hline sh meal & $58 \cdot 3$ & $116 \cdot 7$ & $315 \cdot 3$ \\
\hline d-bone meal & $58 \cdot 3$ & 116.7 & $315 \cdot 3$ \\
\hline in meal & $58 \cdot 3$ & $116 \cdot 7$ & $315 \cdot 3$ \\
\hline ionine & 0.41 & 0.81 & $2 \cdot 20$ \\
\hline hydrochloride & $1 \cdot 0$ & $2 \cdot 0$ & $5 \cdot 4$ \\
\hline chloride & 0.5 & I.O & $2 \cdot 7$ \\
\hline limestone & $3 \cdot I$ & $6 \cdot 2$ & $16 \cdot 8$ \\
\hline- mineral supplement $\dagger$ & 5.0 & $10 \cdot 0$ & $27 \cdot 0$ \\
\hline $\begin{array}{l}\text { tion } \ddagger \\
\text { rotein }(\text { nitrogen } \times 6 \cdot 25)(\mathrm{g} / \mathrm{kg})\end{array}$ & $\begin{array}{l}178 \\
\text { II.90 }\end{array}$ & ${ }_{11}^{252} \cdot 62$ & $\begin{array}{l}516 \\
10 \cdot 12\end{array}$ \\
\hline & 1190 & 11002 & \\
\hline rotein $(\mathrm{g} / \mathrm{kg}) \S$ & 183 & $24 \mathrm{I}$ & 470 \\
\hline
\end{tabular}

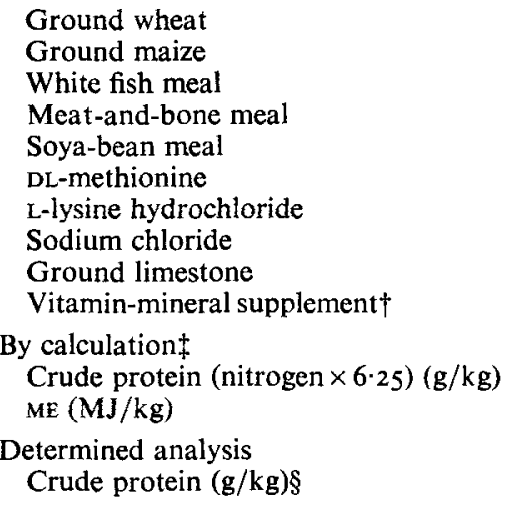

$\mathrm{ME}$, metabolizable energy.

† Standard broiler finisher supplement (Cowan \& Michie, 1978a).

\pm Based on values from published tables (Bolton \& Blair, 1974; De Groote, 1974 for synthetic amino acids). Whole wheat, the alternative food for the free-choice treatments, was considered to contain $104 \mathrm{~g}$ crude protein and I 2. I $8 \mathrm{MJ} \mathrm{ME} / \mathrm{kg}$ (Bolton \& Blair, 1974).

$\S$ The mean of thirteen (diet no. I), seven (diet no. 2) and six (diet no. 3) samples.

At $22 \mathrm{~d}$ of age the broilers in each room were distributed amongst the cages of each tier in that room, twenty-six birds per cage. Six cages per room were randomly assigned to the three feeding treatments of the present experiment, two cages per room per feeding treatment. The cages were 'through' rearing cages $(\mathrm{I} \cdot 2 \mathrm{~m} \times 0.9 \mathrm{~m})$ with a food trough along each long side. A 'nipple' water line was present parallel to and half-way between the food troughs. For the choice-feeding treatments the whole wheat was placed in one trough and the higherprotein food (diets nos 2 or 3 ) placed in the opposite trough. The position of the foods was balanced between the two replicates in each room. Cages receiving the complete diet, diet no. I, received it in both troughs. All foods were supplied ad lib. Regulated quantities of flint grit were supplied during both early rearing and from $22 \mathrm{~d}$; the amount per cage being provided as two approximately equal portions, one portion per food trough. The broilers were maintained under continuous lighting from $\mathrm{I}$ d old and weighed at 22 and $57 \mathrm{~d}$ of age.

The average rate of growth, food intake, whole-wheat intake and higher-protein food (diets nos 2 or 3) intake per bird was determined for each cage for the period 22 to $57 \mathrm{~d}$ of age. Results were statistically analysed by analysis of variance. The data from birds which received diet no. I were also used in the analysis of a separate experiment to investigate the feeding of diets with increased levels of protein at different temperatures (Cowan \& Michie, $1978 b$ ).

\section{RESULTS}

The treatment means and results of the statistical analyses are shown in Tables 2 and 3 .

Growth rate. Broilers which received the complete diet grew at a significantly faster rate than the choice-fed broilers for the 16,21 and $26^{\circ}$ temperature regimens. There was no significant difference in growth rate between the complete diet and the whole-wheat diet no. 2 feeding treatment for the $31^{\circ}$ temperature regimen. For each feeding treatment broilers 
Table 2. Treatment means and results of the statistical analyses for the rate of growth and food intake ( $\mathrm{g} / \mathrm{d}$ per bird) 22-57 $d$, body-weight at $57 d(\mathrm{~kg} /$ bird $)$ and mortality $(\%) 22-57 d$, of broilers given different environmental temperatures and feeding treatments

\begin{tabular}{|c|c|c|c|c|c|}
\hline $\begin{array}{l}\text { Temperature } \\
\text { regimen } \dagger\end{array}$ & Feeding treatment $\ddagger$ & Growth & Food intake & $\begin{array}{c}57 \mathrm{~d} \S \\
\text { body-wt }\end{array}$ & Mortality $+\dagger$ \\
\hline $16^{\circ}$ & $\begin{array}{l}\text { Complete diet } \\
\text { Whole wheat and diet no. } 2 \\
\text { Whole wheat and diet no. } 3\end{array}$ & $\begin{array}{l}44 \cdot 6 \\
42 \cdot 7 \\
38 \cdot 8\end{array}$ & $\begin{array}{r}\text { III.7 } \\
109 \cdot 7 \\
99 \cdot 8\end{array}$ & $\begin{array}{l}I \cdot 992 \\
I \cdot 919 \\
I \cdot 777\end{array}$ & $\begin{array}{l}2 \cdot 0 \\
1 \cdot 9 \\
1 \cdot 9\end{array}$ \\
\hline $21^{\circ}$ & $\begin{array}{l}\text { Complete diet } \\
\text { Whole wheat and diet no. } 2 \\
\text { Whole wheat and diet no. } 3\end{array}$ & $\begin{array}{l}43 \cdot 1 \\
40 \cdot 7 \\
38 \cdot 9\end{array}$ & $\begin{array}{l}106 \cdot 9 \\
104 \cdot 1 \\
97 \cdot 3\end{array}$ & $\begin{array}{l}1 \cdot 935 \\
1 \cdot 852 \\
1 \cdot 779\end{array}$ & $\begin{array}{c}0 \\
1 \cdot 0 \\
0\end{array}$ \\
\hline $26^{\circ}$ & $\begin{array}{l}\text { Complete diet } \\
\text { Whole wheat and diet no. } 2 \\
\text { Whole wheat and diet no. } 3\end{array}$ & $\begin{array}{l}39 \cdot 5 \\
37 \cdot 3 \\
36 \cdot 8\end{array}$ & $\begin{array}{l}93 \cdot 4 \\
89 \cdot 3 \\
87 \cdot 7\end{array}$ & $\begin{array}{l}I \cdot 795 \\
I \cdot 726 \\
I \cdot 696\end{array}$ & $\begin{array}{c}2 \cdot 9 \\
0 \\
1 \cdot 9\end{array}$ \\
\hline $31^{\circ}$ & $\begin{array}{l}\text { Complete diet } \\
\text { Whole wheat and diet no. } 2 \\
\text { Whole wheat and diet no. } 3\end{array}$ & $\begin{array}{l}30 \cdot 9 \\
30 \cdot 0 \\
28 \cdot 5\end{array}$ & $\begin{array}{l}77 \cdot 4 \\
75 \cdot 4 \\
69 \cdot 7\end{array}$ & $\begin{array}{l}I \cdot 454 \\
1 \cdot 430 \\
I \cdot 370\end{array}$ & $\begin{array}{l}I \cdot 0 \\
1 \cdot 9 \\
1 \cdot 9\end{array}$ \\
\hline Main effect $\|$ & $\begin{array}{l}\text { Temperature regimen } \\
\text { Feeding treatment }\end{array}$ & $* * *$ & $* * *$ & $* * *$ & $\begin{array}{l}\text { NS } \\
\text { NS }\end{array}$ \\
\hline $\begin{array}{l}\text { Critical } \\
\text { difference } \mathbb{1} \\
\quad(P<0.05)\end{array}$ & $\begin{array}{l}\mathbf{I} \\
\mathbf{2}\end{array}$ & $\begin{array}{l}1 \cdot 9 \\
2 \cdot 2\end{array}$ & $\begin{array}{l}5 \cdot 3 \\
7 \cdot 6\end{array}$ & $\begin{array}{l}0.067 \\
0.082\end{array}$ & $\begin{array}{l}2 \cdot 8 \\
4 \cdot 4\end{array}$ \\
\hline \multicolumn{6}{|c|}{$\begin{array}{l}\text { NS, not significant; } * * * P<0.00 \mathrm{I} \text {. } \\
\dagger \text { For details, see p. } 3 \mathrm{II} \text {. } \\
\ddagger \text { For details, see Table I. } \\
\S 22 \mathrm{~d} \text { body-weight }(\mathrm{kg} / \text { bird }): 16^{\circ} 0.424,2 \mathrm{I}^{\circ} 0.424,26^{\circ} 0.414,31^{\circ} 0.375 ; \text { critical difference } 0.037 \\
<0.05) \text {. } \\
\text { If The interactions were not significant. } \\
\text { I } 1 \text {, Between feeding treatments for same temperature regimen; } 2 \text {, between the same or different feeding } \\
\text { eatments for different temperature regimens. } \\
\dagger \dagger \text { Including culls. }\end{array}$} \\
\hline
\end{tabular}

kept at $I 6,2 I$ and $26^{\circ}$ grew significantly faster than those kept at $3 I^{\circ}$. Broilers on the complete diet and the whole-wheat diet no. 2 feeding treatment grew significantly faster at $2 I^{\circ}$ compared with $26^{\circ}$ (Table 2).

Food intake. Birds on the complete diet consumed food at a significantly higher rate than those on the whole-wheat and diet no. 3 free-choice feeding treatment, for each temperature treatment. Broilers kept at $\mathrm{I} 6$ and $2 \mathrm{I}^{\circ}$ consumed food at a significantly higher rate than those kept at $26^{\circ}$ which, in turn, had a significantly higher food intake rate than those kept at $31^{\circ}$ for each feeding treatment (Table 2).

Whole wheat and higher-protein food intake. Broilers which received free-choice whole wheat with diet no. 2 consumed the whole wheat at a significantly lower rate and the higherprotein food at a significantly higher rate than the broilers given whole wheat and diet no. 3, for each temperature regimen. For the broilers which received whole wheat and diet no. 2 those kept at 16 and $21^{\circ}$ consumed whole wheat at a significantly higher rate than those kept at $26^{\circ}$ which, in turn, consumed whole wheat at a significantly higher rate than those kept at $31^{\circ}$. For the broilers offered whole wheat and diet no. 3 those kept at $16^{\circ}$ had a significantly higher whole-wheat intake rate than those kept at $26^{\circ}$. while those at $2 \mathrm{I}$ and $26^{\circ}$ consumed whole wheat at a significantly higher rate than the broilers kept at $31^{\circ}$. Differences in the rate of consumption of the higher-protein food between temperature regimens were not significant for broilers fed on whole wheat and diet no. 3 (Table 3 ). 
Table 3. Treatment means and results of the statistical analyses for the rate of whole-wheat $(\mathrm{g})$, higher-protein food $(g)$ (diet no. 2 or 3 ), protein $(g)$ and metabolizable energy (ME) $(M J)$ intake (/bird per $d$ ) 22-57 $d$ for broilers given different environmental temperatures and feeding treatments

Temperature
regimen $\dagger$

$16^{\circ}$

$21^{\circ}$

$6^{\circ}$

$31^{\circ}$

Critical

difference $\mid$

$(P<0.05)$
Feeding treatment $\ddagger$

Complete diet

Whole wheat and diet no. 2

Whole wheat and diet no. 3

Complete diet

Whole wheat and diet no. 2

Whole wheat and diet no. 3

Complete diet

Whole wheat and diet no. 2

Whole wheat and diet no. 3

Complete diet

Whole wheat and diet no. 2

Whole wheat and diet no. 3

Temperature regimen

Feeding treatment

I

2

\begin{tabular}{|c|c|c|c|}
\hline $\begin{array}{l}\text { Whole } \\
\text { wheat }\end{array}$ & $\begin{array}{l}\text { Higher- } \\
\text { protein } \\
\text { food }\end{array}$ & Protein§ & ME§ \\
\hline- & - & $19 \cdot 9$ & $1 \cdot 329$ \\
\hline $60 \cdot 9$ & $48 \cdot 8$ & 18.6 & $1 \cdot 309$ \\
\hline $80 \cdot 3$ & 19.6 & I 8.4 & $1 \cdot 175$ \\
\hline - & - & 19.0 & $1 \cdot 272$ \\
\hline $56 \cdot 9$ & $47 \cdot 2$ & $17 \cdot 8$ & $1 \cdot 242$ \\
\hline $74^{\cdot 2}$ & $23 \cdot I$ & $19 \cdot 7$ & $I \cdot 137$ \\
\hline- & - & 16.6 & $I \cdot 112$ \\
\hline $42 \cdot 9$ & $46 \cdot 4$ & $16 \cdot 2$ & $1 \cdot 062$ \\
\hline $69 \cdot 2$ & $18 \cdot 4$ & 16.7 & $I \cdot 030$ \\
\hline- & - & 13.8 & $0.92 \mathrm{I}$ \\
\hline 34.9 & $40 \cdot 5$ & 13.9 & 0.896 \\
\hline 50.4 & 19.4 & 15.2 & 0.809 \\
\hline$* * *$ & $*$ & $* * *$ & $* * *$ \\
\hline$* * *$ & $* * *$ & NS & $* * *$ \\
\hline $\begin{array}{l}5.9 \\
7.4\end{array}$ & $\begin{array}{l}5.4 \\
5.6\end{array}$ & $\begin{array}{l}I \cdot 5 \\
2 \cdot 0\end{array}$ & $\begin{array}{l}0.064 \\
0.090\end{array}$ \\
\hline
\end{tabular}

NS, not significant.

$* P<0.05, * * * P<0.001$.

$\dagger$ For details, see p. 311

$\ddagger$ For details, see Table $\mathrm{t}$.

$\S$ Results obtained using calculated values for crude protein and ME from Table I.

II The interactions were not significant.

I I, Between feeding treatments for same temperature regimen; 2, between the same or different feeding treatments for different temperature regimens.

\section{DISCUSSION}

Previous studies with broilers fed on a complete diet have shown that food intake of the broiler is inversely related to environmental temperature, growth rate, however, being depressed above approximately $23^{\circ}$ (Prince, Potter \& Irish, I96I ; Milligan \& Winn, I964 Huston, I965; Prince, Whitaker, Matterson \& Luginbahl, I965; Winn \& Godfrey, I967; Deaton, Reece, McNally \& Tarver, 1969; Deaton, Reece, Lott, Kubena \& May, I972; Deaton, Reece, Kubena, May \& Vardaman, 1973). The reduced food intake with increase in environmental temperature implies a reduced intake of protein which may account for the growth rate depression.

Table 3 presents the protein and ME intake rates of the present experiment, calculated using food analysis values from standard tables (Table 1). The choice-fed broiler apparently does not select to maintain its intake of protein regardless of environmental temperature. Indeed the results of Adams, Andrews, Rogler \& Carrick (I962 $a, b$ ); Adams, Andrews, Gardiner \& Carrick (1962); Adams \& Rogler (1968); Kubena, Deaton, Reece, May \& Vardaman (1972) and Cowan \& Michie (1978b), who fed broilers kept under different temperature regimens with diets containing increased levels of either protein, sulphur amino acids, or energy, suggest that much of the growth rate depression is non-nutritional. At temperatures above $23^{\circ}$ the choice-fed broiler may still be selecting to match its protein requirement.

The reason for the reductions in growth rate and food intake rate of the choice-fed broilers 
compared with those fed on the complete diet is not clear. Cowan \& Michie (1978a) reported less pronounced reduced growth rates for the choice-fed broiler. Replacement pullets choice-fed with whole wheat and a higher-protein food containing either $32 \mathrm{I}$ or $490 \mathrm{~g}$ crude protein $/ \mathrm{kg}$ had similar growth rates on average to birds fed on a complete diet regimen (Cowan, Michie \& Roele, 1978).

The authors thank their staff for their assistance and the ARC Unit of Statistics, Edinburgh for carrying out the analyses of variance.

\section{REFERENCES}

Adams, R. L., Andrews, F. N., Gardiner, E. E. \& Carrick, C. W. (1962). Poult. Sci. 4I, 588.

Adams, R. L., Andrews, F. N., Rogler, J. C. \& Carrick, C. W. (1962a). J. Nutr. 77, 121.

Adams, R. L., Andrews, F. N., Rogler, J. C. \& Carrick, C. W. (1962 b). Poult. Sci. 4I, I80r.

Adams, R. L. \& Rogler, J. C. (1968). Poult. Sci. 47, 579.

Bolton, W. \& Blair, R. (1974). Poultry Nutrition London: HMSO.

Cowan, P. J. \& Michie, W. (1978a). Br. Poult. Sci. 19, I49.

Cowan, P. J. \& Michie, W. (I978b). Br. Poult. Sci. (In the Press.)

Cowan, P. J., Michie, W. \& Roele, D. J. (1978). Br. Poult. Sci. 19, 153.

Deaton, J. W., Reece, F. N., Kubena, L. F., May, J. D. \& Vardaman, T. H. (1973). Poult. Sci. 52, II 75.

Deaton, J. W., Reece, F. N., Lott, B. D., Kubena, L. F. \& May, J. D. (1972). Poult. Sci. 51, 69.

Deaton, J. W., Reece, F. N., McNally, E. H. \& Tarver, W. J. (I969). Poult. Sci. 48, 283.

De Groote, G. (1974). In Energy requirements of poultry, p. I 13 [T. R. Morris \& B. M. Freeman, editors]. Edinburgh: British Poultry Science Ltd.

Donhoffer, Sz. \& Vonotsky, J. (1947). Am. J. Physiol. r5o, 329.

Huston, T. M. (1965). Poult. Sci. 44, I032.

Kubena, L. F., Deaton, J. W., Reece, F. N., May, J. D. \& Vardaman, T. H. (1972). Poult. Sci, 5I, I39I.

Leshner, A. I., Collier, G. H. \& Squibb, R. L. (1971). Physiol. Behav. 6, I.

Milligan, J. L. \& Winn, P. N. (1964). Poult. Sci. 43, 817.

Musten, B., Peace, D. \& Anderson, G. H. (1974). J. Nutr. 104, 563.

Prince, R. P., Potter, L. M. \& Irish, W. W. (1961). Poult. Sci. 40, 102.

Prince, R. P., Whitaker, J. H., Matterson, L. D. \& Luginbahl, R. E. (1965). Poult. Sci. 44, 73.

Vohra, P., Wilson, W. O. \& Siopes, T. D. (1975). Proc. Nutr. Soc. 34, 13.

Winn, P. N. \& Godfrey, E. F. (1967). Int. J. Biometeor. 11, 39. 